\title{
Distribúcia verejných zdrojov ako nástroj mobilizácie voleb- nej podpory. Prípad alokácie hasičskej techniky na Slovensku ${ }^{1}$
}

\author{
Veronika Šulková - Peter Spáč ${ }^{2}$ \\ Katedra politologie, Fakulta sociálních studií MU, Brno
}

\begin{abstract}
Distribution of Public Resources as a Tool for Mobilizing Electoral Support. The Case of Allocation of Firefighting Equipment in Slovakia. Research shows that political parties use public resources as a vote-buying mechanism. This paper analyzes the distribution of fire engines to Slovak municipalities before 2016 election. We find that towns with mayors from the ruling party as well as municipalities where this party scored better in previous election were advantaged in the selection process. We also show that grants increase the electoral support of the ruling party and even more substantially they boost the share of votes of the government representative who personally directed the distribution. This positive effect is strongest in smaller municipalities and it weakens with rising town population. Sociológia 2021, Vol. 53 (No. 4: 377-399)

https://doi.org/10.31577/sociologia.2021.53.4.14
\end{abstract}

Key words: Pork barrel politics; elections; grants; Slovakia; municipalities

\section{Úvod}

Rozhodovanie o pridel'ovaní prostriedkov je bežnou kompetenciou vlád a ich ministerstiev. Z ekonomického hl'adiska sa distribúcia zdrojov realizuje typicky za účelom dosahovania efektivity ako maximalizácie návratnosti, alebo rovnosti, teda s ciel'om kompenzovat' rozdiely medzi jednotlivými územiami (Boex - Martinez-Vazquez 2005). Napriek významu týchto hodnôt, prax ukazuje, že ich nasledovanie nemusí byt' pri alokácii verejných peňazí prvoradé. Primárnym dôvodom je to, že proces distribúcie realizujú a kontrolujú politické strany, ktorých prirodzenou ambíciou je získat' a udržat' si moc, a to prostredníctvom voličských hlasov. V dôsledku toho tak do rozdel'ovania verejných zdrojov vstupujú aj konkrétne politické a stranícke záujmy.

Popísaný fenomén politiky vykrmovania (z angl. pork barrel politics) bol pôvodne spájaný predovšetkým s prostredím USA. Tamojší politický systém, federalizmus, podoba politických strán a previazanost' členov Kongresu na jednotlivé štáty vytvorili podmienky pre uplatňovanie danej praxe v rozsiahlej miere. Typicky tak územne koncentrované benefity slúžia ako prostriedok k zaisteniu podpory pre navrhovanú legislatívu s predpokladom, že voliči $\mathrm{v}$ takto podporených štátoch danú aktivitu ocenia. Ako však ukazuje existujúca literatúra, distribúcia zdrojov ovplyvnená politickými záujmami je podstatne

\footnotetext{
1 Tento text vznikol za podpory projektu Distributivní politika ve střední Evropě (GA18-16928S) financovaného Grantovou agentúrou Českej republiky (GA ČR).

${ }^{2}$ Korešpondencia: doc. Peter Spáč, Ph.D., Katedra politologie, Fakulta sociálních studií, Masarykova univerzita, Joštova 10, 60200 Brno, Česká republika. E-mail: spac@fss.muni.cz. Mgr. Veronika Šulková, e-mail: 439665@mail.muni.cz
} 
rozšírenejším fenoménom a prechádza naprieč krajinami aj politickými systémami (Costa-I-Font et al 2003; Golden - Picci 2008; Miligan - Smart 2005; Stratmann - Baur 2002; Veiga - Veiga 2013).

Tento text sa zaoberá distribúciou hasičskej techniky v období pred parlamentnými vol'bami v roku 2016 na Slovensku. V rámci uvedenej alokácie boli pridel'ované hasičské autá do obcí, pričom celý proces podliehal Ministerstvu vnútra SR. Text sleduje dva hlavné ciele. Prvým je identifikácia, či do procesu pridel'ovania popísanej techniky zasahovali i konkrétne politické faktory. Druhým ciel’om je posúdenie, či poskytnutie hasičských áut v období predchádzajúcom konaniu volieb do Národnej rady Slovenskej republiky v roku 2016 malo dopad na ich výsledky.

Štruktúra textu je nasledovná. Nasledujúca kapitola približuje teoretické východiská politiky vykrmovania a jej dopady na volebnú sút'až. Ďalšia čast' popisuje dobrovol'né hasičské zbory obcí na Slovensku a tiež samotný distribučný proces skúmanej hasičskej techniky realizovaný v období pred parlamentnými vol'bami 2016. Text pokračuje kapitolou venovanou výskumnému rámcu, dátam a použitým metódam. Následne sú predstavené výsledky a hlavné zistenia sú zhrnuté v závere textu.

\section{Politické pozadie pridel’ovania dotácií a ich efekty}

Termín pork barrel politics sa vamerickom prostredí už v priebehu 19. storočia vžil pre označenie legislatívy, ktorá obsahovala projekty pre obvody členov Kongresu, aby tak boli motivovaní podporit' navrhovanú legislatívu. Pejoratívny názov zodpovedá častému postoju verejnosti $\mathrm{k}$ tejto praxi, ktorá je bežná dodnes. Na druhej strane, dané praktiky nebývajú vnímané len vo výhradne negatívnom slova zmysle. Ako uvádza Evans (2004), tento postup môže byt' pre legislatívnu činnost' prospešný v situácii, kedy politické strany nie sú schopné zaistit' dostatočnú disciplínu vlastných volených reprezentantov. Vo výsledku tak dochádza $\mathrm{k}$ prijatiu legislatívy, ktorej prínos presahuje partikulárne výhody poskytnuté vybraným členom Kongresu, resp. štátom, kde sú volení.

Politika vykrmovania sa vo všeobecnosti dá definovat' ako poskytovanie koncentrovaných materiálnych výhod do vybraných územných oblastí, pričom náklady tohto postupu nesie celá spoločnost', a to typicky formou všeobecného systému zdaňovania (Weingast et al. 1981). Čast' autorov ešte $\mathrm{k}$ tomuto vymedzeniu pripája redistribúciu programatickú, zahŕňajúcu opatrenia pre rôzne skupiny spoločnosti formou penzií a obdobných dávok (porov. Dixit - Londregan 1996; Stokes et al 2013).

Samotná podoba politiky vykrmovania podstatne závisí od konkrétneho kontextu, v ktorom sa realizuje. V prostredí slabších a vol'nejších politických strán, kam spadá už uvedený príklad USA, dochádza k poskytovaniu výhod 
výmenou za podporu legislatívy. V praxi tak benefity z distribúcie získavajú predstavitelia vládnych i opozičných strán. Na rozdiel od toho, v krajinách, kde politické strany mocensky prevažujú nad jednotlivými volenými zástupcami, čoho príkladom je i Európa, má politika vykrmovania inú podobu. V tomto nastavení je rozdelovanie zdrojov centralizované a pod priamou kontrolou vlád. Zdroje sú tak alokované v súlade so záujmami vládnych subjektov, naopak opozícia je v tejto situácii skôr penalizovaná (porov. Hoare 1992).

K politike vykrmovania dochádza na základe rôznych motívov, ktoré sa navzájom môžu prelínat'. V rámci literatúry je často uvádzaná distribúcia verejných zdrojov ako nástroj odmeňovania, či naopak trestania predošlého volebného správania. Inými slovami, zdroje sú v tomto kontexte koncentrované s ohl'adom na predošlé volebné výsledky. Autori pritom rozlišujú dva základné prístupy. Prvým je nasmerovanie prostriedkov primárne do oblastí, kde vládne strany získavajú vysokú a stabilnú podporu. Týmto spôsobom tak dochádza k odmeňovaniu volebných bášt vládnych subjektov, čím sa má tento status daných území upevnit' (porov. Cox - McCubbins 1986). Naopak alternatívou je taktika podpory oblastí s menej stabilným elektorátom, kde vládna strana čelí riziku porážky. V tomto ponímaní vládne strany adresujú zdroje viac do oblastí, kde je ich vít’azstvo neisté a poskytnuté prostriedky majú dopomôct' $\mathrm{k}$ jeho zaisteniu (Dixit - Londregan 1996). Oba uvedené scenáre prešli v d’alšom období rozsiahlym testovaním, ktorého výsledky sú však zmiešané, pretože ani jeden z nich nebol jednoznačne potvrdený ako dominantný (porov. Dahlberg - Johansson 2002; Dellmuth - Stoffel 2012; Golden - Picci 2008; Schraff 2014; Solé-Ollé - Sorribas-Navarro 2008).

Častým motívom pre realizáciu politiky vykrmovania je podpora individuálnych volených predstavitel'ov vládnych strán na nižších územných úrovniach. Týmto spôsobom je daným reprezentantom umožnené získat' zásluhy za prichádzajúce zdroje a tým posilnit' svoje vyhliadky v nadchádzajúcich vol'bách. Daný prístup potvrdila Khemani (2003), ktorá sa venovala prípadu Indie. Konkrétne, ukázala, že tamojšia centrálna vláda zaistuje prostriedky primárne pre tie indické štáty, ktorých vedenia sú s ňou politicky spriaznené. Tento aspekt ešte zvýraznili Milligan a Smart (2005), ktorých analýza prípadu Kanady preukázala, že objem poskytovaných verejných zdrojov do jednotlivých území súvisel s tým, akú pozíciu zastávali ich reprezentanti v straníckej hierarchii alebo v samotnom politickom systéme. Nakoniec, Bueno (2018) na prípade Brazílie ukazuje nielen tendenciu vlády pridel'ovat' prostriedky oblastiam vedeným starostami z radov vládnej strany, ale súčasne i snahu zamedzit' opozícii pripísat' si zásluhy za prísun zdrojov do oblastí pod jej kontrolou. Pre dosiahnutie tohto ciel'a využila vláda stratégiu alokácie prostriedkov do opozičných samospráv cez lokálne neštátne organizácie. 
Klúčovým aspektom politiky vykrmovania sú aj jej očakávané následky. Alokácia prostriedkov v súlade so záujmami politických strán je typicky realizovaná s ciel'om zaistit' konkrétnym predstavitel'om volebnú podporu. Medzi autormi pritom neexistuje zhoda v tom, či u voličov pod vplyvom materiálnych benefitov dochádza $\mathrm{k}$ úprave ich volebného správania. Jednou stranou tejto diskusie je teória zodpovednej vlády, podla ktorej voliči disponujú sadou hodnôt, prostredníctvom ktorej hodnotia ponuku politických strán, rozhodujú o svojej vol'be a neskôr spätne vyhodnocujú výkon vlády. Oproti tomu existujú teórie, na základe ktorých je pre voličov podstatnejší samotný dosiahnutý výsledok než deklarované hodnoty (porov. Downs 1957; Mayhew 1974).

Očakávaná účinnost' politiky vykrmovania je založená na predpoklade, že občania primárne vnímajú dosiahnuté výsledky, a teda by mali ocenit' materiálne benefity poskytnuté ich územiu. Následne by tak vo výsledku mali vo vyššej miere podporit’ tie politické subjekty, ktoré si za prísun zdrojov dokážu pripísat' zásluhy. Dôležitou podmienkou tohto scenára pritom je, aby alokované prostriedky predstavovali pre lokalitu viditel'ný prínos a mohli tak byt' občanmi priamo vnímané. Podstatne silnejší potenciál zasiahnut' voličov tak majú napríklad dotácie spojené s rekonštrukciou infraštruktúry než finančné injekcie, ktoré znížia (pre voličov skôr abstraktnú) zadížzenost' regiónu (porov. Stein Bickers 1994; Veiga - Veiga 2013).

I ked' literatúra $\mathrm{v}$ danom ohl'ade nie je úplne jednotná, viacerí autori preukázali dopad distribúcie verejných zdrojov na volebné výsledky. Dvojica Levitt a Snyder (1997) v prípade amerického Kongresu potvrdila vzt'ah medzi zvýšením federálnych výdavkov v konkrétnej oblasti a šancou získat' hlasy vo vol'bách. Podla ich výsledkov, každých 100 dolárov na hlavu predstavovalo zvýšenie volebnej podpory kandidátov o dve percentá. Tento záver potvrdil i Stratmann (2013), pričom jeho analýza ukázala, že efekt obdobného objemu vynaložených prostriedkov na volebné výsledky je ešte silnejší.

Kl'účovým atribútom pre volených reprezentantov je schopnost' pripísania si zásluh za prísun verejných prostriedkov. Inými slovami, je zásadný rozdiel medzi samotnou distribúciou dotácií a schopnostou príslušných reprezentantov presvedčit' občanov, že na danej skutočnosti majú vlastný podiel (porov. Klingensmith 2019; Samuels 2002). To, že už samotné prisúdenie kreditu za poskytovanie zdrojov má potenciál zvýšit' objem voličských hlasov, potvrdila Papp (2019) v rámci analýzy dotácií z Európskeho štrukturálneho fondu v Mad'arsku. Konkrétne zistila, že hoci vládni poslanci mad'arského parlamentu v tomto procese nemajú žiadne formálne postavenie, v praxi sa usilujú o pripísanie si zásluh za pridelené prostriedky, čo im v lokalitách s väčším objemom alokovaných dotácií zaist'uje vyššiu voličskú podporu. 
Vyššie spomenuté faktory, teda viditel'nost' dotácií verejnost'ou či jednoduchost' pripísania zásluh, môžu významne závisiet' od kontextu, v ktorom sa odohrávajú. Konkrétne materiálne benefity, akými sú výstavby budov, dodávky materiálu či usporiadanie akcií, sú viac poznatel'né v menších lokalitách. Súvisí to nielen s menším fyzickým priestorom, ktorý zaistuje, že výsledky realizovanej dotácie sú jednoduchšie viditel'né pre obyvatel'ov, ale i so spôsobom šírenia informácií a charakterom kontaktov (porov. Oliver et al. 2012). V menej l'udnatých sídlach je taktiež prítomné silnejšie zapojenie verejnosti do lokálnych záležitostí a vyšší záujem l'udí o toto dianie (Bryan 2004). Na základe toho je možné predpokladat', že politika vykrmovania má silnejší potenciál ovplyvnit' voličské správanie v menších sídlach, ked’že s ohl'adom na jednoduchšie sprostredkovanie informácií o poskytnutých dotáciách, tu dochádza k intenzívnejšiemu pripísaniu si zásluh pre zainteresované politické subjekty a ich predstavitel'ov.

V domácom prostredí je politika vykrmovania v posledných rokoch predmetom narastajúceho výskumného záujmu. Výskumy zo susednej Českej republiky preukázali, že k prieniku politických záujmov do alokácie verejných zdrojov dochádza ako na celoštátnej, tak i regionálnej úrovni (Hána 2014; Hána - Macešková 2010; Spáč et al. 2018). Obdobné zistenia boli preukázané i na Slovensku (porov. Spáč 2016), a to predovšetkým v spojitosti so zvýhodnením obcí vedených predstavitel'mi zvolenými s podporou vládnych politických strán. Uvedené závery len potvrdzujú geografickú rozšírenost' fenoménu politiky vykrmovania. Doterajší výskum v prípade Slovenska pritom preukázal i dopad poskytovaných zdrojov na vol'by, ked' identifikoval, ako rôzne stratégie distribúcie ovplyvňujú sút'až o posty starostov a primátorov (Spáč 2020). Určitou medzerou tak zostáva analýza vplyvu alokovaných prostriedkov na vol’by na ostatných územných úrovniach, a to primárne na celoštátnej, čo sa usiluje preklenút' i tento text.

\section{Pridel'ovanie hasičskej techniky na Slovensku}

Dobrovol'né hasičské zbory majú na Slovensku dlhú tradíciu a ich zriadenie je pre obce povinné. Výnimku majú obce, ktoré majú menej ako 500 obyvatelov alebo sa dohodli na plnení týchto úloh s Hasičským a záchranným zborom alebo hasičskou jednotkou právnickej alebo podnikajúcej fyzickej osoby. Ďalšou možnost'ou je po dohode s okresným riaditel'stvom vytvorit' spoločný zbor. Úlohy dobrovol'ných hasičských zborov sa líšia v závislosti od ich kategorizácie. Dobrovol'né hasičské zbory obcí (DHZO) sú registrované v Celoplošnom rozmiestnení síl a prostriedkov hasičských jednotiek na území Slovenskej republiky. O registráciu DHZO žiada obec, ktorá je zriad'ovatel'om, avšak zároveň sa môžu registrovat' aj zbory, ktoré vznikli ako občianske združenia. Krajské riaditel'stvá následne zbory rozrad’ujú do kategórií A1, A, 
$\mathrm{B}, \mathrm{C}$ a $\mathrm{D}$, a to na základe nebezpečenstva katastrálneho územia obce. Do kategórie D sú zaradené zbory, ktoré nepožiadali o registráciu. Kým najvyššia kategória A1 má byt' schopná plnohodnotne zastúpit' hasičský zbor, ostatné kategórie plnia skôr podpornú funkciu pri náročnejších zásahoch. Mimo to je ich úlohou vzdelávanie $\mathrm{v}$ téme ochrany pred požiarmi (Vyhláška MV SR č. 201/2015 Z.z.). Často sa tiež zúčastňujú na hasičských športových sút'ažiach, pričom pre niektoré DHZO je to dominantná činnost' (Transparency International Slovensko 2015).

S povinnost'ou zriadit' hasičský zbor prichádza aj povinnost' zriad'ovatel'a udržiavat' ho funkčný. Táto okolnost' môže byt' problematická predovšetkým pre menšie obce, ktoré pracujú s menším rozpočtom. Problému vybavenosti dobrovol'ných hasičských zborov sa začala venovat' zvýšená pozornost' v roku 2010, kedy sa táto téma dostala aj do programového vyhlásenia vlády (Programové vyhlásenie Vlády SR na obdobie rokov 2010 - 2014). Od roku 2014 je dobrovol'ným hasičským zborom poskytovaná paušálna finančná podpora, ktorej výška závisí od zaradenia zboru do kategórie ${ }^{3}$.

Okrem tejto podpory bolo dôležitým krokom rozhodnutie o postupnej obnove techniky, prostredníctvom nových a repasovaných hasičských vozidiel, a to pod gesciou Ministerstva vnútra SR. O pridelenie vozidla mohli žiadat' bud' samotné DHZO, prípadne ich zriad'ovatelia. Bližšie pravidlá výberu dobrovol'ných hasičských zborov, ktorým bola technika pridelená však na webových stránkach Ministerstva vnútra SR neboli uvedené. V odpovedi na žiadost' o sprístupnenie informácií ministerstvo uviedlo, že “vozidlá boli pridel’ované na základe splnenia podmienok kategorizácie v plošnom rozmiestnení síl a prostriedkov, za podmienok stanovených rozhodnutím o poskytnutí nenávratného finančného príspevku“. Prípadný bodový systém hodnotenia či zoznam s hodnoteniami obcí, ktoré so žiadost’ou uspeli, sprístupnené neboli. Pravidlá a procesy skúmaného kola pridel'ovania hasičskej techniky tak možno hodnotit' ako značne netransparentné.

S uvedenou distribúciou hasičskej techniky sa začalo už počas obdobia vlády Ivety Radičovej. K zásadnému zintenzívneniu tejto činnosti však došlo až po vol'bách 2012, v ktorých strana SMER-SD získala väčšinu mandátov v parlamente a utvorila vládu bez potreby akýchkol'vek koaličných partnerov. Počas tohto volebného obdobia realizovalo Ministerstvo vnútra SR pod vedením Roberta Kaliňáka sútaž, ktorá viedla k nákupu 550 vozidiel za viac ako 57 miliónov eur ${ }^{4}$. Samotná distribúcia tejto techniky sa stala predmetom

\footnotetext{
${ }^{3}$ Výška poskytovaného paušálneho príspevku reflektuje odlišné nároky na jednotlivé kategórie. Od roku 2017 je tento príspevok pridel’ovaný v nasledujúcich výškach: 7000 eur pre zbor zaradený v kategórii A1, 5000 eur pre zbor zaradený v kategórii A, 3000 eur pre zbor zaradený v kategórii B, 1400 eur pre zbor zaradený v kategórii C (Vyhláška Ministerstva vnútra SR 30/2017 Z.z.).

4 Pre porovnanie, počas vlády Ivety Radičovej bolo týmto spôsobom pridelených 120 vozidiel, teda menej ako štvrtina z počtu hasičských áut alokovaných vo volebnom období $2012-2016$.
} 
záujmu médií i neziskového sektoru, a to $\mathrm{v}$ spojitosti $\mathrm{s}$ vyššie uvedenými nejasnými pravidlami výberu príjemcov techniky a tiež i s ohl'adom na načasovanie a praktické prevedenie celého procesu. Obciam, ktorých žiadosti o pridelenie techniky uspeli, boli prvozásahové vozidlá slávnostne odovzdané ministrom vnútra, a to za účasti predstavitel'ov obce, DHZO a tiež obyvatel'ov obce. Vo viacerých obciach mal akt odovzdania vozidla charakter slávnosti $\mathrm{s}$ účast'ou folklórnych súborov či hudobníkov (TASR 2015).

$\mathrm{Z}$ vedeckého pohl'adu tak sledovaný prípad pridel'ovania hasičskej techniky na Slovensku počas druhej vlády Roberta Fica otvára dva okruhy otázok. Prvý sa vzt'ahuje k výberu obcí, ktorým bola pridelená hasičská technika. Nejasnost' pravidiel a vol'nost' rozhodovania subjektu, ktorý kontroluje alokačný proces, predstavujú základné predpoklady pre realizáciu politiky vykrmovania (Milligan - Smart 2005), pretože umožňujú, aby výsledky distribúcie zdrojov boli ovplyvnené politickými záujmami, v tomto prípade strany SMER-SD. Druhá čast' otázok sa týka dopadov distribúcie prostriedkov na volebnú sút'až. Existujúca literatúra poukazuje na to, že vhodné načasovanie alokovaných zdrojov krátko pred vol'bami má potenciál zvýšit' politickým subjektom ich podporu u voličov (Samuels 2002). Okolnosti skúmaného pridel'ovania hasičských vozidiel do tejto logiky v plnej miere zapadajú, ked’že dodatky $\mathrm{k}$ rámcovej zmluvy určovali čas dodania tak, aby boli vozidlá odovzdané do volieb v roku 2016 (Centrálny register zmlúv 2014). Obdobne možno hasičskú techniku považovat' za charakter materiálneho benefitu s potenciálom ovplyvnit' voličské chovanie. Jednotliví autori sa zhodujú v tom, že pre vyvolanie požadovaných účinkov je nevyhnutné, aby poskytované materiálne benefity boli dostatočne viditel'né pre miestne obyvatel'stvo. $\mathrm{Z}$ dostupnej literatúry pritom pre účinky politiky vykrmovania nevyplývajú žiadne sektorové obmedzenia (porov. Bruhn 1996; De La O 2013; Evans 2006; Leigh 2008; Thachil 2011), z čoho možno vyvodit', že k ovplyvneniu volebného chovania môže potenciálne dôjst' prostredníctvom akýchkol'vek dotácií, ktoré vedú k fyzicky vnímatel'ným výsledkom, a to bez ohl'adu na to, či ide o oblast' školstva, životného prostredia či cestnej infraštruktúry. Na základe toho konštatujeme, že je výskumne relevantné analyzovat' ako výsledky procesu distribúcie hasičskej techniky na Slovensku, tak i jej dopady na volebnú sút’až.

\section{Výskumný rámec, dáta a metódy}

Ciel'om tohto textu je analyzovat' distribúciu hasičskej techniky z centrálnej na lokálnu úroveň na Slovensku počas druhej vlády Roberta Fica v období predchádzajúcom parlamentné vol'by v roku 2016. Článok pokrýva dva hlavné ciele. Po prvé, $\mathrm{s}$ ohl'adom na teoretické východiská a podobu procesu alokácie hasičských vozidiel, bude sledované, či pridel'ovanie týchto zdrojov prebiehalo nezávisle na politických faktoroch. Predošlý výskum preukázal, že k motívom 
politiky vykrmovania náleží odmeňovanie voličov za predošlú podporu a tiež poskytovanie pomoci individuálnym predstavitel'om vládnych strán, ktorí pôsobia vo volených funkciách na nižších územných úrovniach. Pridel'ovanie hasičských vozidiel na Slovensku predstavuje formu dotácií poskytovaných lokálnej úrovni, teda obciam a mestám, čo znamená, že tento mechanizmus umožňuje testovat' oba spomenuté motívy. V rámci analýzy tak bude zist'ované, či vyhliadky obcí na pridelenie dotácie pred vol'bami 2016 ovplyvňovala stranícka príslušnost' ich starostov (vo vzt’ahu k vláde) a tiež to, aký výsledok tu zaznamenala vládna strana SMER-SD v predchádzajúcich parlamentných vol'bách. Na základe toho formulujeme prvé dve hypotézy:

H1: Obce vedené starostami zvolenými s podporou vládnej strany majú vyššiu pravdepodobnost' získat' dotáciu.

H2: Vyšší podiel hlasov vládnej strany v obci v predchádzajúcich parlamentných vol'bách zvyšuje pravdepodobnost' obce na zisk dotácie.

Druhým ciel'om textu je skúmat' dopady pridelenia prostriedkov na výsledky volieb. S ohl'adom na časové náležitosti distribúcie (vid' predošlá kapitola) budú analyzované parlamentné vol’by v roku 2016. Z teórie vyplýva, že primárnym ciel’om politiky vykrmovania je zaistenie podpory občanov prostredníctvom poskytovania materiálnych benefitov. Kl'účovým atribútom v tomto zmysle je schopnost' pripísania si zásluh za alokované zdroje, aby si voliči pridelené dotácie dokázali spojit's konkrétnym politickým subjektom či osobou. S ohl'adom na to, že distribúcia hasičských vozidiel pred vol'bami 2016 prebiehala počas vládnutia strany SMER-SD, dá sa predpokladat', že uvedené zásluhy mohli byt' z pohl'adu obyvatel'ov dotknutých obcí vztiahnuté práve $\mathrm{k}$ tejto politickej formácii. Obdobné pripísanie zásluh sa dá predpokladat' tiež v spojitosti s vtedajším ministrom vnútra Kaliňákom, ktorý sa zúčastňoval slávnostných odovzdávaní hasičskej techniky. Nakoniec, ako u strany SMER$\mathrm{SD}$, tak i u ministra Kaliňáka predpokladáme, že pozitívny dopad dotácií na ich volebnú podporu bude silnejší v menších obciach, ked'že $\mathrm{v}$ nich je pripisovanie zásluh za poskytnuté zdroje intenzívnejšie. Vychádzajúc z toho formulujeme zostávajúce hypotézy.

H3: Pridelenie dotácie zvyšuje lokálnu podporu vládnej strany v parlamentných vol'bách.

H4: Pridelenie dotácie zvyšuje lokálnu volebnú podporu predstavitel'a vlády, ktorý priamo participuje na distribúcii zdrojov.

H5: Pozitívny dopad dotácií na podporu vládnej strany $\mathrm{v}$ parlamentných vol'bách rastie s klesajúcou populáciou obce. 
H6: Pozitívny dopad dotácií na lokálnu volebnú podporu predstavitel'a vlády, ktorý priamo participuje na distribúcii zdrojov, rastie s klesajúcou populáciou obce.

Nasleduje priblíženie premenných. V rámci analýzy pridel'ovania dotácií sledujeme, či obce získali alebo nezískali hasičskú techniku. Závislá premenná je tak binárna a nadobúda hodnotu 1 pre obce s prideleným autom a 0 pre obce, ktoré auto nezískali. Nezávislé premenné tu pokrývajú podporu strany SMER$\mathrm{SD}$, resp. stranícku príslušnost' starostov. Prvá z týchto premenných je intervalová a jej hodnoty vyjadrujú percentuálny podiel hlasov, ktorý strana SMERSD získala v obciach v parlamentných vol'bách 2012.

Podoba nezávislej premennej mapujúcej stranícku príslušnost' starostov si vyžaduje podrobnejší popis. Starostovia (a primátori) sú na Slovensku priamo volení, pričom môžu kandidovat' bud' ako nezávislí alebo ako nominanti jednej strany či koalície viacerých subjektov. S ohl'adom na to, že v rokoch 2012 až 2016 bola vo vláde iba strana SMER-SD, rozlišujeme celkom tri kategórie straníckej príslušnosti starostov. Prvou sú starostovia zvolení s podporou strany SMER-SD, teda subjektu, ktorý kontroloval distribúciu skúmanej hasičskej techniky. Druhú skupinu tvoria nezávislí starostovia a tret’ou sú starostovia za všetky ostatné (teda opozičné) strany. Daná nezávislá premenná je tak kategoriálna s tromi možnými hodnotami.

Čo sa týka kontrolných premenných, vo výskume politiky vykrmovania ich typicky tvoria kritériá vybranej dotačnej schémy. Z odpovede Ministerstva vnútra SR na informačnú žiadost' je možné vyvodit', že k týmto parametrom náležala kategorizácia DHZO. Dôvodom je skutočnost', že pri rozdel'ovaní techniky malo byt' prihliadané $\mathrm{k}$ nebezpečenstvu katastra obce, ktoré sa pre jednotlivé kategórie v rámci registrácie DHZO líši ${ }^{5}$. Pre tento účel tak bola vytvorená premenná pokrývajúca celkom tri kategórie dobrovol’ných hasičských zborov, menovite A (vrátane A1), B a $\mathrm{C}^{6}$. Ked’že zborom vyššej kategórie je poskytovaná vyššia paušálna náhrada, predpokladáme, že aj v pridel'ovaní vozidiel sa kategorizácia DHZO prejaví a prednost' budú mat’ zbory vo vyšších kategóriách.

Dalšie kontrolné premenné pokrývajú charakteristiky samotných obcí. Dôvodom je skutočnost', že v rámci distribúcie verejných zdrojov môže za

\footnotetext{
5 Kritériá boli zistované priamo na MV SR formou žiadosti o informácie. Plné znenie odpovede je nasledovné: "Vozidlá boli pridel'ované na základe splnenia podmienok kategorizácie v plošnom rozmiestnení síl a prostriedkov, za podmienok stanovených rozhodnutím o poskytnutí nenávratného finančného príspevku. Plnenie podmienok kategorizácie jednotlivých DHZO zaradených do plošného rozmiestnenia síl a prostriedkov je pravidelne kontrolované vrátane plnenia podmienok užívania predmetu výpožičky v súlade so zmluvou o výpožičke techniky podpísanej so zriad'ovatel'om príslušného DHZO, ktorému bola technika pridelená."

6 Je pritom vhodné poznamenat', že o registráciu kategórie môžu žiadat' nielen obce, ale aj ich časti či dokonca občianske združenia. V prípadoch, kedy bol hasičský zbor zaregistrovaný ku konkrétnej časti obce a nie k obci samotnej, boli tieto údaje priradené na vyššiu, teda obecnú úroveň.
} 
účelom vyrovnávania rozdielov existovat' tendencia podporovat' ekonomicky slabšie subjekty. K tým bývajú typicky radené menšie lokality, pre ktoré môže byt' oproti l'udnatejším sídlam finančne náročnejšie poskytovat' určité služby. Do analýzy tak zarad'ujeme aj premennú pokrývajúcu vel'kost' obyvatel'stva obcí, pričom jej hodnoty využívame v logaritmovanej podobe. $\mathrm{Z}$ dostupných ekonomických ukazovatel'ov tiež ako kontrolné premenné zarad'ujeme úroveň nezamestnanosti a tiež finančné zdravie obcí, ktoré pokrýva index vypracovaný Inštitútom pre ekonomické a sociálne reformy ${ }^{7}$. Medzi kontrolné premenné je tiež zaradený podiel občanov mad’arskej národnosti, a to $\mathrm{s}$ ohl'adom na historicky ukotvenú polarizáciu, ktorá sa prejavuje aj v politickej oblasti (Mesežnikov 2004; Petőcz 2004). S ohl'adom na to, že v rokoch 2012 až 2016 nemala žiadna mad'arská strana vládne zastúpenie, je možné predpokladat', že na obce $\mathrm{s}$ vyšším zastúpením príslušníkov tejto menšiny to v rámci distribúcie hasičskej techniky mohlo mat' negatívny dopad.

V prípade analýzy dopadov pridel'ovania dotácií na volebné výsledky pracujeme s dvomi samostatnými závislými premennými. Prvá sa týka volebnej podpory strany SMER-SD, je intervalová a jej hodnoty zodpovedajú percentuálnemu podielu hlasov, ktoré tento subjekt získal v parlamentných vol'bách 2016 na úrovni obcí. Druhá závislá premenná pokrýva podporu ministra vnútra. Pre tento jav sledujeme s ohl'adom na podobu volebného systému podiel prednostných hlasov, ktoré Robert Kaliňák vo vol'bách 2016 v rámci obcí získal. Daný podiel je počítaný z celkového počtu získaných hlasov strany SMER-SD v obci, a teda môže v percentuálnom vyjadrení nadobúdat' hodnoty od 0 do 100 . Nezávislá premenná pre túto čast' analýzy mapuje výsledky distribúcie hasičskej techniky. Daná premenná je binárna a má hodnotu 1 pre obce, ktoré získali auto a 0 pre ostatné obce.

Ako kontrolné premenné využívame sériu sociodemografických charakteristík obcí, ktoré sú často využívané vo volebnej geografii a z ktorých viaceré boli $\mathrm{v}$ predošlom výskume identifikované ako faktory ovplyvňujúce podporu strany SMER-SD (porov. Madleňák 2012; Pink et al. 2012; Spáč - Havlík 2015). Väčšina týchto premenných je identická ako kontrolné premenné pre prvú čast' analýzy, a to vel'kost' miestnej populácie, úroveň nezamestnanosti a finančné zdravie obcí. Okrem toho tiež sledujeme vekovú štruktúru obcí, a to podiel starších l'udí vo veku 60 a viac rokov, d’alej podiel praktizujúcich veriacich numericky najvýznamnejšieho rímskokatolíckeho vyznania a z hl'adiska vzdelania zarad’ujeme premennú pokrývajúcu podiel obyvatel’ov s vysokoškolským vzdelaním. Nakoniec kontrolujeme vplyv predošlej podpory strany SMER-SD, resp. Roberta Kaliňáka z volieb do NR SR 2012. Dôvodom je

\footnotetext{
7 Hodnotenie sa zameriava na udržatel'nost' hospodárenia obcí. Do výpočtu je zahrnutá séria ukazovatel’ov, a to celkový dlh, dlhová služba, bilancia bežného účtu, záväzky po splatnosti k príjmom a záväzky aspoň 60 dní po splatnosti. Najväčšiu váhu (30\%) má celkový dlh obce a bilancia bežného účtu (INEKO - Hospodárenie obcí, nedatované).
} 
predpoklad vysokej asociácie medzi teritoriálnou distribúciou získaných hlasov medzi oboma vol'bami.

Čo sa týka zdrojov dát, tie boli získavané od verejných inštitúcií, prípadne boli obdržané na základe informačných žiadostí. Údaje o distribúcii hasičskej techniky poskytlo na základe žiadosti Ministerstvo vnútra SR. Informácie o kategorizácii jednotlivých DHZO sú dostupné na stránkach Dobrovolnej požiarnej ochrany. Výsledky volieb a údaje o straníckej príslušnosti starostov obcí pochádzajú z verejne dostupných dát Štatistického úradu SR. Jednotlivé sociodemografické charakteristiky obcí, teda národnostné, vekové, vzdelanostné a náboženské zloženie obyvatel'stva je založené na údajoch zo Sčítania obyvatel'ov, domov a bytov z roku 2011 (Hlavac 2016). Hodnoty finančného zdravia obcí boli získané od INEKO a nakoniec hodnoty úrovne nezamestnanosti boli spočítané pomocou kombinácie dát o počte uchádzačov o zamestnanie $\mathrm{v}$ obciach $\mathrm{z}$ dát Ústredia práce, sociálnych vecí a rodiny a ekonomicky aktívneho obyvatel'stva. Tieto údaje boli vyžiadané za september 2015 , ked’že hlavná vlna pridel'ovania techniky prebiehala v druhej polovici roku 2015.

Posledná poznámka sa týka metód a podoby analýzy. Pre rozbor výsledkov distribúcie hasičskej techniky pracujeme s binárnou závislou premennou a na základe toho bude použitá binárna logistická regresia. Do príslušných modelov budú použité všetky slovenské obce, ktoré mohli byt' potenciálnymi príjemcami poskytovanej techniky a súčasne ich DHZO spadá do vyššie popísanej kategorizácie. Tieto podmienky splńa 1400 obcí. Pre druhú čast' analýzy o dopadoch pridelených prostriedkov na volebné výsledky majú obe závislé premenné intervalovú povahu, na základe čoho bude použitá OLS regresia. Pre tieto modely budú využité všetky slovenské obce, pričom mestské časti Bratislavy a Košíc tu budú chápané ako samostatné jednotky.

\section{Výsledky}

Ako prvé prezentujeme výsledky analýzy distribúcie hasičskej techniky do obcí. Tie obsahuje model 1, ktorý je zobrazený v tabul'ke č. 1. Výsledky ukazujú, že šance na pridelenie dotácie mali obce s rastúcou vel'kost'ou populácie a tiež so stúpajúcim zastúpením mad’arskej menšiny. Naopak vyššia nezamestnanost' a lepšie finančné zdravie tieto vyhliadky obcí znižovali. V rámci kontrolných premenných malo najvýznamnejší dopad na výstupy rozdel'ovania zdrojov zaradenie DHZO. Ako vyplýva z nameraných dát, v rámci alokácie techniky boli viac preferované obce, ktorých dobrovol'ní hasiči boli zaradení do prioritnejších kategórií. $\mathrm{V}$ porovnaní s kategóriou $\mathrm{C}$, ktorá bola $\mathrm{v}$ modeli využitá ako referenčná kategória, mali ostatné obce významne vyššie šance na to, že im bude pridelené hasičské auto. Konkrétne, u obcí spadajúcich pod kategóriu $\mathrm{A}$, boli tieto šance viac ako dvojnásobné a v prípade municipalít s DHZO zaradenými do skupiny $\mathrm{B}$ dokonca viac než trojnásobné. Formálna hierarchia 
DHZO, ktorá má dopad aj na ich rozdielne pravidelné financovanie štátom (vid' vyššie) sa tak pretavila i do výsledkov distribúcie hasičskej techniky.

\section{Tabul'ka č. 1: Analýza distribúcie hasičskej techniky do obcí ${ }^{8}$}

\begin{tabular}{lccc}
\hline & \multicolumn{3}{c}{ Model 1 } \\
\cline { 2 - 4 } & B & SE & OR \\
\hline SMER-SD 2012 & .018 & .006 & 1.019 \\
Starosta & & & \\
$\quad$ SMER-SD & .338 & .171 & 1.402 \\
$\quad$ Nezávislý & .104 & .162 & 1.109 \\
$\quad$ Opozícia (ref.) & & & \\
Kategorizácia DHZO & & & \\
$\quad$ Kat. A & .769 & .251 & 2.157 \\
$\quad$ Kat. B & 1.208 & .135 & 3.348 \\
$\quad$ Kat. C (ref.) & & & \\
Obyvatelia (log) & .037 & .059 & 1.038 \\
Mad'ari & .012 & .005 & 1.012 \\
Nezamestnanost' & -.007 & .006 & .993 \\
Finančné zdravie & -.222 & .118 & .801 \\
Konštanta & -1.523 & .837 & .218 \\
\hline N & & 1400 & \\
Nagelkerke R ${ }^{2}$ & & .115 & \\
\hline
\end{tabular}

Klúčovým zistením vyplývajúcim z analýzy je skutočnost', že výstupy rozdel'ovania skúmaných zdrojov boli ovplyvnené politickými faktormi. Čo sa týka straníckej príslušnosti starostov, najnižšie vyhliadky na pridelenie techniky mali obce vedené nominantmi opozície (referenčná kategória v modeli 1). V porovnaní s nimi mali lokality s nezávislými starostami šancu na zisk dotácie približne o $10 \%$ vyššiu. Najlepšiu pozíciu zo všetkých mali obce, kde pôsobili starostovia zvolení s podporou vtedajšej vládnej strany SMER-SD. Ich šance na pridelenie hasičského auta boli o $40 \%$ vyššie než v prípade obcí so starostami za opozičné strany.

Pre lepšie vecné vyjadrenie efektu afiliácie starostov sme spočítali odhadované pravdepodobnosti úspechu obcí v distribučnom procese. Pre tento účel sme ostatné premenné ukotvili na hodnote ich priemeru a v prípade kategorizácie DHZO sme zvolili skupinu A. V prípade takto definovaných obcí, tie so starostami za opozičné strany mali odhadovanú pravdepodobnost' zisku hasičského auta necelých $32 \%$. U identických obcí, avšak s nezávislými starostami sa táto pravdepodobnost' zvýšila na viac ako $34 \%$. Nakoniec, ak

\footnotetext{
${ }^{8}$ V jednotlivých stípcoch sú zl’ava zobrazené regresné koeficienty, štandardné chyby a pomery šancí. Vzhl’adom na to, že pracujeme s kompletným súborom dát, nevyužívame ako ukazovatel' štatistickú signifikantnost'.
} 
v takto určených lokalitách figurovali starostovia zvolení s podporou strany SMER-SD, bola pravdepodobnost' na pridelenie techniky takmer $40 \%$. Afiliácia starostov na vládnu stranu tak znamenala pre príslušné obce posilnenie ich vyhliadok na prísun verejných zdrojov, čo poskytuje podporu pre našu prvú hypotézu.

Graf č. 1: Pravdepodobnost' zisku techniky podl'a podpory strany SMERSD vo vol'bách 2012

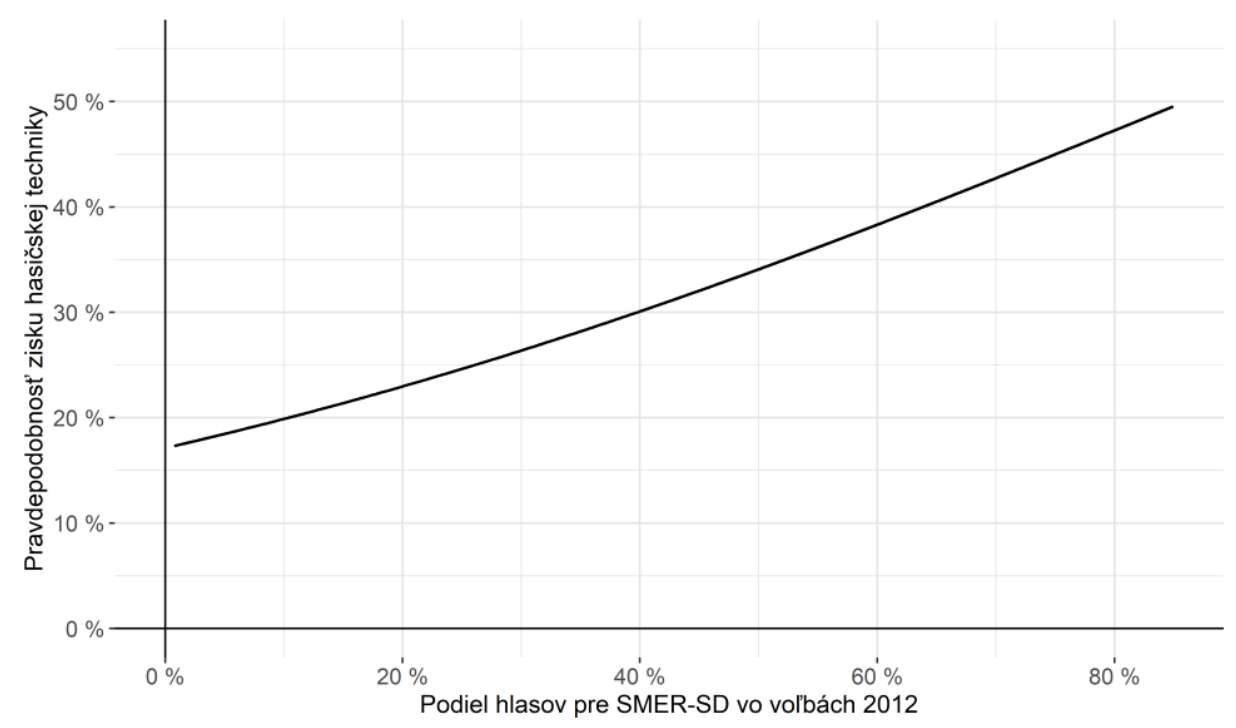

Model 1 ukazuje, že lepšie vyhliadky na pridelenie techniky mali obce, kde strana SMER-SD v parlamentných vol'bách 2012, ktoré analyzovanej distribúcii predchádzali, dosahovala lepšie výsledky. S ohl'adom na typ tejto premennej bol jej efekt vizualizovaný (graf č. 1). Obdobne ako v prípade straníckej afiliácie starostov, i tu využívame odhadované pravdepodobnosti. Pre ich spočítanie boli hodnoty ostatných intervalových premenných ukotvené na svojom priemere, z kategórií DHZO bola zvolená skupina A v prípade starostov boli vybraní nezávislí. Ako vyplýva z grafického zobrazenia, výška podielu hlasov pre SMER-SD vo vol'bách 2012 mala významný dopad na pravdepodobnost' obcí na získanie hasičskej techniky. 10-percentná podpora pre SMER-SD znamenala pre takto definované obce pravdepodobnost' pridelenia áut na úrovni $20 \%$. V prípade, že podiel hlasov pre SMER-SD dosiahol $40 \%$, čo bolo len niekol'ko percentuálnych bodov pod jeho vtedajším celoštátnym ziskom, daná pravdepodobnost' stúpla na $30 \%$. Nakoniec, ak bol SMERSD v obci vel'mi úspešný a jeho zisk sa pohyboval okolo $80 \%$ získaných hlasov, pravdepodobnost', že takejto obci bude udelená dotácia sa blížila 
k $50 \%$. Platí tak, že lokálny výsledok strany SMER-SD vo vol'bách časovo predchádzajúcich posudzovanej distribúcii predstavoval zásadný faktor ovplyvňujúci vyhliadky daných obcí na to, či sa stali príjemcom pridel'ovanej hasičskej techniky. Tento záver poskytuje oporu pre našu druhú hypotézu.

Tabul'ka č. 2: Vplyv pridelených zdrojov na volebné výsledky ${ }^{9}$

\begin{tabular}{|c|c|c|c|c|c|c|c|c|}
\hline & \multicolumn{2}{|c|}{$\begin{array}{c}\text { Model } 2 \\
\text { (SMER-SD) }\end{array}$} & \multicolumn{2}{|c|}{$\begin{array}{c}\text { Model 3 } \\
\text { (R. Kaliňák) }\end{array}$} & \multicolumn{2}{|c|}{$\begin{array}{c}\text { Model } 4 \\
\text { (SMER-SD) }\end{array}$} & \multicolumn{2}{|c|}{$\begin{array}{c}\text { Model } 5 \\
\text { (R. Kaliňák) }\end{array}$} \\
\hline & B & SE & B & SE & B & SE & B & SE \\
\hline Dotácia & .511 & .311 & 4.487 & .543 & 4.207 & 1.997 & 19.604 & 3.497 \\
\hline SMER-SD 2012 & .648 & .006 & - & - & .648 & .006 & - & - \\
\hline Kaliňák 2012 & - & - & .393 & .019 & - & - & .393 & .019 \\
\hline Obyvatelia (log) & -.079 & .124 & -.802 & .216 & .011 & .133 & -.433 & .231 \\
\hline Nezamestnanost' & .071 & .012 & -.061 & .021 & .072 & .012 & -.056 & .021 \\
\hline Finančné zdravie & -.219 & .232 & -.132 & .406 & -.216 & .232 & -.121 & .405 \\
\hline Podiel 60+ & .141 & .024 & -.065 & .042 & .146 & .024 & -.045 & .042 \\
\hline Vysokoškoláci & -.180 & .033 & -.122 & .058 & -.178 & .033 & -.117 & .058 \\
\hline Katolíci & -.024 & .005 & .017 & .008 & -.024 & .005 & .016 & .008 \\
\hline Dotácia*Ob. (log) & - & - & - & - & -.534 & .285 & -2.183 & .499 \\
\hline Konštanta & 1.965 & 1.797 & 40.742 & 3.242 & 1.253 & 1.836 & 37.834 & 3.300 \\
\hline $\mathrm{N}$ & \multicolumn{2}{|c|}{2910} & \multicolumn{2}{|c|}{2910} & \multicolumn{2}{|c|}{2910} & \multicolumn{2}{|c|}{2910} \\
\hline $\mathrm{R}^{2}$ & \multicolumn{2}{|c|}{.808} & \multicolumn{2}{|c|}{.151} & \multicolumn{2}{|c|}{.808} & \multicolumn{2}{|c|}{.156} \\
\hline
\end{tabular}

V druhej časti analýzy bude pozornost' venovaná dopadom pridelenej hasičskej techniky na výsledky strany SMER-SD, resp. Roberta Kaliňáka vo vol'bách v roku 2016 (tab. 2). Namerané hodnoty ukazujú, že strane SMER-SD sa v týchto vol'bách viac darilo v prostredí s vyšším zastúpením starších l'udí či vyššou nezamestnanost'ou a naopak jej podpora klesala s narastajúcim podielom obyvatel'ov s vysokoškolským vzdelaním. Úspešnost' R. Kaliňáka bola taktiež nižšia v prostredí $\mathrm{s}$ väčším zastúpením osôb s univerzitným titulom a menej sa mu darilo i v l'udnatejších sídlach. Pre oba subjekty, teda pre SMER-SD i pre vtedajšieho ministra vnútra spoločne platilo, že geografická štruktúra ich podpory v roku 2016 bola silne asociovaná $\mathrm{s}$ ich výsledkami z predchádzajúcich parlamentných volieb.

\footnotetext{
${ }^{9}$ V jednotlivých stípcoch sú zl’ava zobrazené neštandardizované B koeficienty a štandardné chyby. Vzhl’adom na to, že pracujeme s kompletným súborom dát, nevyužívame ako ukazovatel' štatistickú signifikantnost'. Podiel vysvetlenej variability sa medzi modelmi značne odlišuje. Konkrétne, v prípade modelov vysvetl'ujúcich podporu strany SMER-SD sú dané hodnoty podstatne vyššie ako v modeloch, ktoré analyzujú prednostné hlasy pre Roberta Kaliňáka. Daný rozdiel poukazuje na vyššiu schopnost' vysvetlit' pomocou agregovaných dát variabilitu hlasov pre politické strany oproti variabilite pridelených prednostných hlasov pre ich individuálnych predstavitel’ov. V prípade Roberta Kaliňáka to naznačuje, že na výšku jeho prednostných hlasov mali dopad i d’alšie nezmapované faktory (vrátane tých na úrovni jednotlivcov), kým premenné, ktoré na základe literatúry (Madleňák 2012; Pink et al. 2012; Spáč - Havlík 2015) dokážu pomerne dobre vysvetlit' podporu strany SMER-SD, nemajú pre analýzu hlasov jeho osoby natol'ko silnú výpovednú hodnotu.
} 
Čo sa týka samotného dopadu alokovaných prostriedkov, z modelu 2 vyplýva, že prísun hasičskej techniky mal na výšku podpory strany SMER-SD len nevýznamný dopad. Podl'a dosiahnutých výsledkov, v obciach, ktoré boli úspešnými príjemcami dotácie, bol výsledok tejto strany vyšší len o pol percentuálneho bodu. Na rozdiel od toho, Robert Kaliňák (model 3) v týchto lokalitách zaznamenal $\mathrm{v}$ prednostnom hlasovaní až o takmer 4,5 percentuálneho bodu lepší výsledok než v obciach, ktoré hasičské auto nezískali. Výstupy modelov 2 a 3 tak naznačujú, že kým pre SMER-SD distribúcia techniky do obcí neviedla k zvýšeniu jeho podpory, priama angažovanost' vtedajšieho ministra vnútra na danom distribučnom procese, resp. na akciách s ním spojených, znamenala nárast jeho osobnej popularity, čo sa pretavilo i do výsledkov volieb v roku 2016. Dané závery tak poskytujú oporu pre hypotézu 4, nie však pre hypotézu 3.

Graf č. 2: Podpora SMER-SD vo vol'bách 2016 podl'a pridelených dotácií a počtu obyvatel'ov (Model 4)

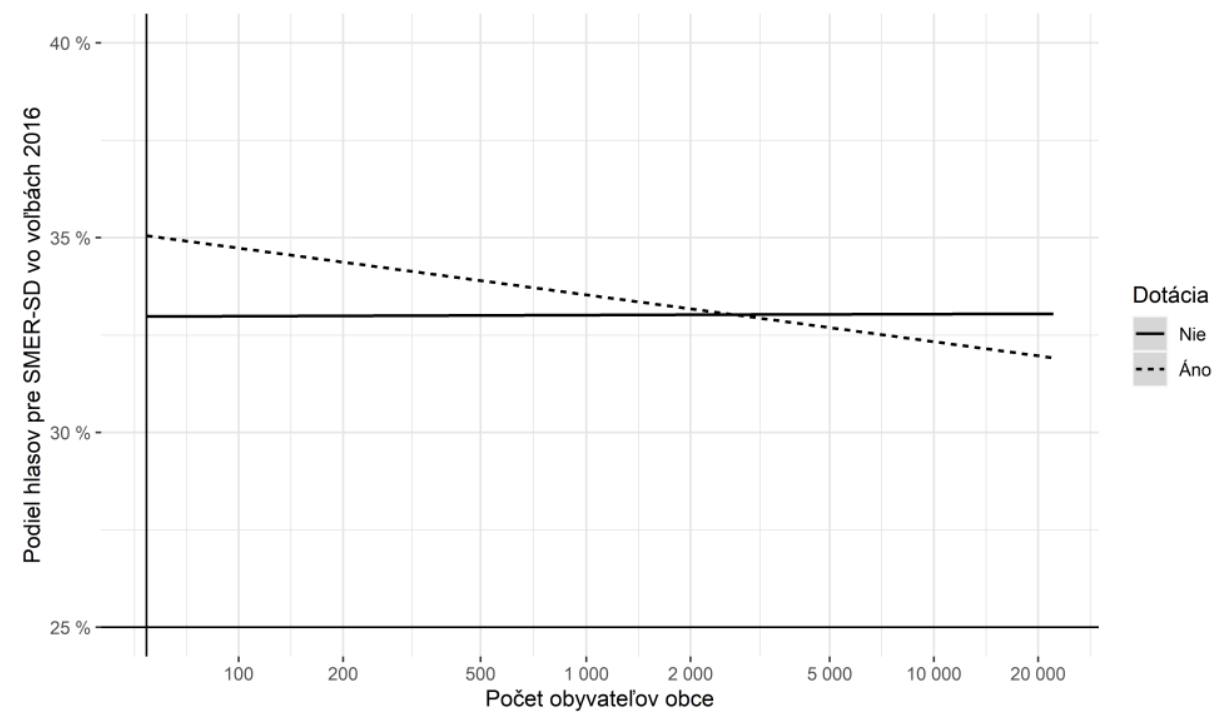

Modely 4 a 5 vysvetlujú podporu SMERu-SD, resp. podiel prednostných hlasov R. Kaliňáka aj s použitím interakcie medzi poskytnutými dotáciami a vel'kost'ou obyvatel'stva. Výsledky ukazujú, že pre SMER-SD (graf č. 2) bola distribúcia hasičských áut do určitej miery prospešná, avšak výhradne $\mathrm{v}$ obciach s malým počtom obyvatel'ov. I v nich pritom rozsah tohto efektu nebol zásadný. Konkrétne vobciach so 100 obyvatel'mi zvyšoval prísun techniky zisk SMERu-SD len o necelé dva percentuálne body. S narastajúcou vel'kost'ou populácie sa daný efekt oslaboval, ked' v lokalitách s 500 l'ud'mi 
znamenal pre podporu SMER-SD nárast o menej ako jeden percentuálny bod. V prípade obcí s tisíc a viac obyvatel'mi už prísun hasičskej techniky pre SMER-SD neznamenal žiadny prospech. Vo všeobecnosti tak SMER-SD ako strana z procesu distribúcie áut vo vol'bách 2016 významnejšie netažil.

Graf č. 3: Podpora R. Kaliňáka vo vol'bách 2016 podl’a pridelených dotácií a počtu obyvatel'ov (Model 5)

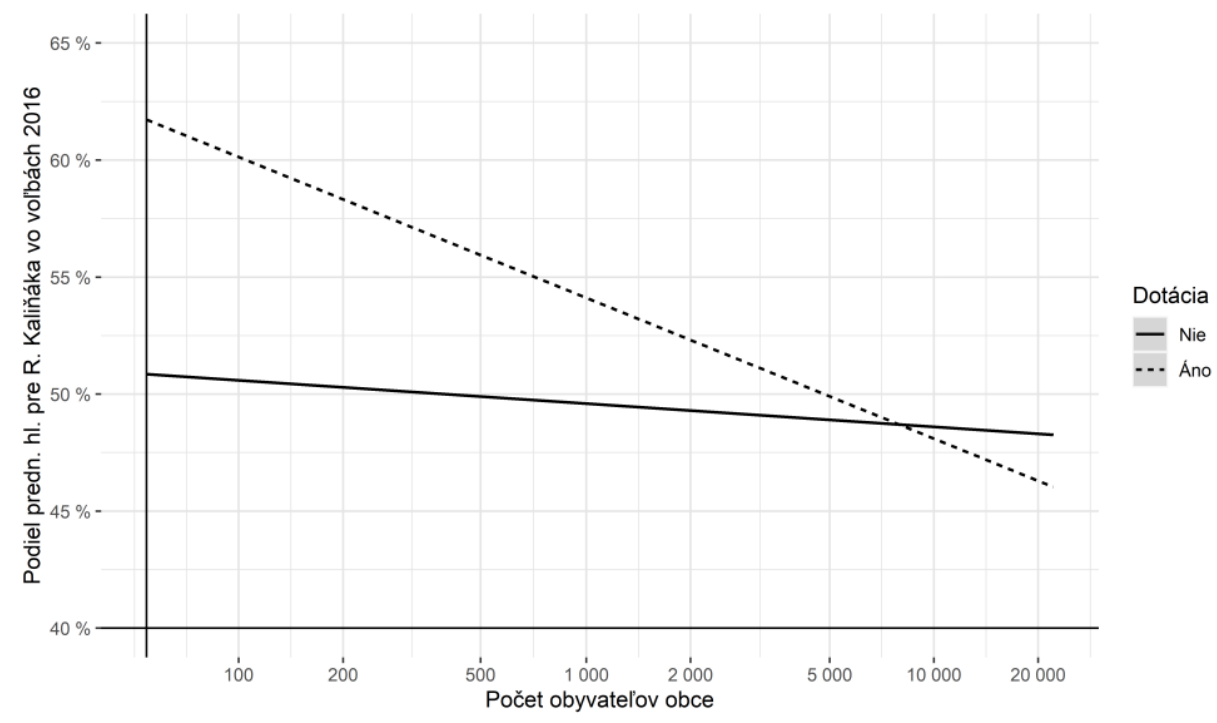

Na rozdiel od svojej materskej strany, pre Roberta Kaliňáka znamenala osobná angažovanost' pri alokácii hasičskej techniky nárast jeho vlastnej popularity (model 5). Výsledky ukazujú, že vyššie komentovaný pozitívny vplyv pridelených áut na jeho podporu bol spojený predovšetkým s menšími obcami (graf č. 3). Hoci sa vizualizácia tohto efektu svojím tvarom podobá na zobrazené výstupy pre stranu SMER-SD (porov. graf č. 2), dá sa hovorit' o dvoch dôležitých rozdieloch.

Prvým je rozsah efektu. Kým pozitívny vplyv prísunu hasičskej techniky do menších obcí znamenal pre SMER-SD nárast jeho podpory o jeden až dva percentuálne body, v prípade Roberta Kaliňáka bol daný efekt podstatne silnejší. Pre porovnanie, v obciach so 100 obyvatel'mi bol zisk auta spojený so zvýšením podielu jeho prednostných hlasov o 10 percentuálnych bodov. V obciach s 200 l'ud'mi išlo o nárast daného podielu o 8 a v lokalitách s populáciou 500 osôb o 6 percentuálnych bodov. Druhý rozdiel sa týka trvania popisovaného efektu v závislosti na vel'kosti obyvatel'stva. Kladný dopad distribúcie áut na podporu Roberta Kaliňáka sa, podobne ako u jeho strany, tiež postupne znižoval so stúpajúcou vel'kost'ou lokálnej populácie, avšak 
pomalším tempom. Kým vobciach s 1000 obyvatel'mi nemal už prísun techniky na výšku podpory SMERu-SD žiadny vplyv, pre vtedajšieho ministra vnútra to $\mathrm{v}$ rovnakom prostredí znamenalo nad’alej nárast podielu jeho preferenčných hlasov o 5 percentuálnych bodov. K vytrateniu tohto efektu tak v prípade Roberta Kaliňáka došlo až v lokalitách s približne 5000 l’ud'mi, teda $\mathrm{v}$ mieste postupného prechodu $\mathrm{k}$ mestskému prostrediu. Vo väčších sídlach už prípadný prísun hasičských áut $\mathrm{k}$ podielu jeho prednostných hlasov žiadnym spôsobom neprispieval.

Výsledky analýzy tak preukázali dosah distribúcie hasičskej techniky na výsledky volieb 2016. Čo sa týka strany SMER-SD, ktorá v danom období predstavovala jedinú vládnu stranu, pozitívny vplyv pridelených áut na jej podporu sa dostavil len $\mathrm{v}$ obmedzenej miere, a to výhradne v prostredí najmenších obcí. Na rozdiel od toho, pre Roberta Kaliňáka sa riadenie celého procesu, resp. i jeho osobná participácia pri odovzdávaní techniky, ukázali ako značne prospešné. Hoci i v jeho prípade sa pozitívny efekt pridelených áut na podiel jeho preferenčných hlasov oslaboval s narastajúcou vel'kost'ou obyvatel'stva, čo do rozsahu bol však významnejší než u jeho vlastnej strany a vytrval i v prostredí stredných a väčších obcí. Na základe toho možno konštatovat', že z posledných dvoch hypotéz poskytli dosiahnuté výsledky silnejšiu oporu pre hypotézu 5 o moderujúcom účinku vel'kosti obyvatel'stva na vplyv dotácií na podporu osobne zainteresovaného vládneho predstavitel'a do procesu distribúcie verejných zdrojov.

\section{Záver}

Distribúcia verejných prostriedkov náleží k základným atribútom realizácie politickej moci. Politické strany prostredníctvom svojich nominantov kontrolujú významné zdroje finančných prostriedkov, ktorých alokáciu môžu do určitej miery ovplyvňovat' v súlade s vlastnými záujmami. Existujúci výskum v tejto oblasti preukázal, že naprieč štátmi majú politické faktory vplyv na výsledky rozdel'ovania verejných peňazí. Týmto spôsobom dochádza $\mathrm{k}$ zacieleniu prostriedkov do vybraných oblastí, a to primárne s ambíciou zaistenia voličskej podpory u lokálneho obyvatel'stva (Klingensmith 2019; Stratmann Baur 2002; Veiga - Veiga 2013).

Náš výskum analyzoval distribúciu hasičskej techniky do slovenských obcí v období pred parlamentnými vol'bami v roku 2016. Výsledky analýzy ukázali, že uvedený alokačný proces nebol nezávislý od politických faktorov, ked' výhodnejšie postavenie mali obce vedené starostami zvolenými s podporou vtedajšej vládnej strany SMER-SD a taktiež lokality, kde táto politická formácia dosiahla lepšie výsledky vo vol'bách v roku 2012. Tieto zistenia podporujú teoretický predpoklad, že dotačné finančné toky koncentrujú centrálne vlády do oblastí, kde dosahujú vysokú a stabilnú podporu (porov. 
Cox - McCubbins 1986). Súčasne dané výsledky podporujú predošlú literatúru, ktorá identifikovala, že k poskytovaniu materiálnych benefitov z centrálnej úrovne dochádza primárne do oblastí vedených predstavitel'mi so straníckou príslušnost’ou blízkou celoštátnej vláde (porov. Khemani 2003).

$\mathrm{V}$ texte sme tiež posudzovali dopady pridelenej techniky na výsledky volieb 2016 v spojitosti s aktérmi ovládajúcimi daný distribučný proces. Zistili sme, že prísun hasičských áut do obcí mal za následok predovšetkým zvýšenie podielu prednostných hlasov pre vtedajšieho ministra Kaliňáka, ktorý celý proces zaštit'oval a osobne na ňom participoval. Tento efekt bol pritom najsilnejší v malých obciach a s nárastom vel'kosti obyvatel'stva sa postupne oslaboval, až sa v mestskom prostredí stal vecne bezvýznamným. V prípade samotnej strany SMER-SD analýza ukázala obdobný trend, avšak v podstatne menšom rozsahu a len v prostredí najmenších obcí.

Tieto zistenia zapadajú do poznatkov predošlého výskumu a tiež ho dopíňajú a obohacujú. Konkrétne sa preukázalo, že pre vyvolanie požadovaných účinkov na volebné výsledky je kl'účovým atribútom schopnost' pripísania zásluh za pridelené dotácie (porov. Klingensmith 2019; Samuels 2002). Skutočnost', že alokácia hasičských áut bola prospešnejšia pre výsledky Roberta Kaliňáka než strany SMER-SD, je možné vysvetlit' jeho angažovanost’ou v danom procese, čo v praktickej rovine znamenalo jeho osobnú účast' na slávnostnom odovzdávaní techniky obciam. Javí sa tak, že jeho prítomnost' na daných akciách umožnila obyvatel'om obce utvorit' asociáciu medzi ním a poskytnutým materiálnym benefitom, čo vo výsledku posilnilo zisk jeho preferenčných hlasov vo vol'bách ${ }^{10}$. S ohl'adom na to, že poskytnutie hasičskej techniky viedlo k určitému, aj ked' len obmedzenému, nárastu podpory i strany SMER-SD, dá sa predpokladat', že voliči zásluhy pripísali i tejto politickej formácií, avšak v nie obdobnej intenzite ako vo vzt’ahu k osobe ministra vnútra. To indikuje, že z pohl'adu voličov môžu byt' politické strany t’ažšie zhmotnitel'né ako prijímatelia zásluh za konkrétne materiálne benefity a táto rola je jednoduchšia pre ich predstavitel'ov, ktorí sú priamo angažovaní v celom distribučnom procese. Naše výsledky tak ukazujú na dôležitost' osobnej participácie zainteresovaných politických reprezentantov v procese alokácie zdrojov ${ }^{11}$. Tento poznatok tak oproti nami skúmaným parlamentným vol'bám založeným na pravidlách pomerného systému, môže byt' ešte významnejší

\footnotetext{
10 Dostupné dáta pritom neumožňujú identifikovat', či sa Robert Kaliňák osobne zúčastnil odovzdávania všetkých hasičských áut. Existujúce informácie však naznačujú, že bol v tomto zmysle značne aktívny (porov. Kováč 2016; Kováč 2019; Mikušovič 2017; TASR 2015). Dá sa tak predpokladat', že ak Robert Kaliňák osobne neparticipoval na odovzdávaní všetkých hasičských áut, pozitívny efekt jeho priamej angažovanosti v danom procese na objem jeho prednostných hlasov môže byt' ešte výraznejší, než ukázala naša analýza.

11 Dá sa predpokladat', že čast' zisteného pozitívneho dopadu na volebné výsledky strany SMER-SD bola spôsobená nárastom tamojšej osobnej popularity Roberta Kaliňáka, ktorý tak pre svoju stranu nepriamo zaistil nových voličov. Tento scenár však nie je možné spol’ahlivo overit', a to s ohl'adom na neexistenciu potrebných dát na individuálnej úrovni, skúmajúcich podrobné motívy voličov jednotlivých strán v parlamentných vol'bách.
} 
v prípade d’alších volebných sútaží na Slovensku, kde voliči udel'ujú svoje hlasy nie politickým stranám, ale priamo individuálnym kandidátom.

Výsledky rozširujúce existujúce poznanie $\mathrm{v}$ tejto oblasti sa týkajú i moderujúceho efektu vel'kosti obyvatel'stva. Naša analýza ukázala, že k jednoduchšiemu pripísaniu zásluh za pridelené benefity dochádza $\mathrm{v}$ menej l'udnatých sídlach. To potvrdzuje, že v menších obciach, ktoré sa vyznačujú vyšším záujmom miestneho obyvatel'stva o lokálne dianie (porov. Bryan 2004), sú alokované prostriedky jednoduchšie viditel'né pre obyvatel'ov, zasahujú väčší okruh voličov a v súhrne tak poskytujú silnejšiu návratnost' v podobe hlasov vo vol'bách. Dané zistenie tak naznačuje, že z hl'adiska ciel'ov politiky vykrmovania je pre subjekty ovládajúce distribúciu výhodnejšie, nasmerovat' prostriedky do menších lokalít, ked’že v l'udnatejších sídlach je efekt poskytovaných benefitov na volebné správanie slabší.

Popri dosiahnutých výsledkoch je vhodné zmienit' aj limity našej analýzy. Je dôležité zdôraznit', že náš výskum je založený na agregovaných dátach, z ktorých nie je možné vyvodzovat' priame závery platné pre individuálnu úroveň. Existencia dát na úrovni voličov by pritom objektívne umožnila zlepšit' stav poznania $\mathrm{v}$ tejto oblasti. Ako podotýka čast' autorov, pridel'ovanie dotácií môže mat' na voličov rozdielne účinky (Samuels 2002; Kligensmith 2019). Nie je tiež vylúčené, že poskytované materiálne benefity majú vplyv iba na určitý typ voličov, čo okrem iného môže súvisiet's rozdielnou mierou ich informovanosti a povedomia o distribučných procesoch a ich výsledkoch (Sidman 2019; Stein - Bickers 1994). Výskum, ktorý by reagoval na uvedené predpoklady s ciel'om posúdit' mieru vplyvu alokovaných zdrojov na rôzne skupiny voličov, by vyžadoval zapojenie dát na individuálnej úrovni, ktoré však momentálne nie sú dostupné.

Náš text prispel i k domácemu výskumu, ked’ preukázal, že materiálne prostriedky poskytované formou dotácií obciam, majú vplyv nielen na miestne vol'by (porov. Spáč 2020), ale i na sút'až na celoštátnej úrovni, konkrétne na parlamentné vol'by. Ďalší výskum by sa tak mal zamerat' na posúdenie vplyvu distribúcie zdrojov na zostávajúce typy volieb, pričom ako dôležitá sa javí analýza volieb do orgánov samosprávnych krajov, ked’že ide o jediný formát sútaže, ktorý na Slovensku prebieha na regionálnej územnej úrovni. Ako vhodné sa ukazuje tiež zapojenie analýz na individuálnej úrovni, prostredníctvom čoho by bolo možné lepšie zmapovat' voličské správanie a jeho motívy.

$\mathrm{V}$ neposlednom rade a vychádzajúc $\mathrm{z}$ nami dosiahnutých výsledkov by sa d’alšie analýzy mohli koncentrovat' i na otázku osobnej participácie politických predstavitel’ov v distribučnom procese. Náš text na príklade Roberta Kaliňáka preukázal, že priame angažovanie politikov má potenciál posilnit' ich osobnú popularitu, ktorá sa pretaví i do podoby volebných výsledkov. Nad’alej tu však zostáva priestor pre identifikáciu faktorov, ktoré ovplyvňujú, či a v akej miere 
dôjde zo strany voličov k prideleniu príslušných zásluh. Inými slovami, javí sa ako dôležité objasnit', či je pre prisúdenie zásluh postačujúca samotná účast' politika na odovzdaní materiálneho benefitu alebo či do tohto procesu vstupujú i d'alšie faktory typu charakteru samotného aktu udelenia dotácie, jeho nákladnosti, jeho časových náležitostí či podoby sprievodného programu pre verejnost'. Sledovanie týchto línií výskumu by malo podporit' naše poznanie pridel'ovania zdrojov a ich dôsledkov, teda oblasti, ktorá je významná ako po teoretickej, tak i spoločenskej stránke.

Veronika Šulková je absolventkou magisterského štúdia na Katedre politologie Fakulty sociálnich studii Masarykovej univerzity v Brne so zameraním na volebné śtúdia a politický marketing. $V$ súčasnosti pôsobi ako analytička na Útvare hodnoty za peniaze Ministerstva financii SR.

Peter Spáč pôsobi ako docent na Katedre politologie Fakulty sociálních studii Masarykovej univerzity v Brne. Odborne sa zameriava na volebné reformy, volebné správanie a verejné financovanie. Svoje texty publikoval v časopisoch Contemporary Politics, Government Information Quarterly, Public Choice alebo East European Politics and Societies.

\section{LITERATÚRA}

BOEX, J. - MARTINEZ-VAZQUEZ, J., 2005: The Determinants of the Incidence of Intergovernmental Grants: A Survey of the International Experience. Working Paper 06-52 (http://papers.ssrn.com/sol3/papers.cfm?abstract_id=902454).

BRUHN, K., 1996: Social Spending and Political Support: The "Lessons" of the National Solidarity Program in Mexico. Comparative Politics 28(2): 151-177.

BRYAN, F. M., 2004: Real Democracy: The New England Town Meeting and how it Works. Chicago: University of Chicago Press.

BUENO, N. S., 2018: Bypassing the Enemy: Distributive Politics, Credit Claiming, and Nonstate Organizations in Brazil. Comparative Political Studies 51(3): 304340. DOI: https://doi.org/10.1177/0010414017710255.

COSTA-I-FONT, J. - RODRIGUEZ-ORREGIA, E. - LUNAPLA, D., 2003: Political Competition and Pork-Barrel Politics in the Allocation of Public Investment in Mexico. Public Choice 116(1-2): 185-204.

COX, G. W. - MCCUBBINS, M. D., 1986: Electoral Politics as a Redistributive Game. The Journal Of Politics 48(2): 370-389. DOI: https://doi.org/10.2307/2131098.

Centrálny register zmlúv, 2014 (https://www.crz.gov.sk/1344814/).

DAHLBERG, M. - JOHANSSON, E., 2002: On the Vote-Purchasing Behavior of Incumbent Governments. The American Political Science Review 96(1): 27-40.

DE LA O, A., 2013: Do Conditional Cash Transfers Affect Electoral Behavior? Evidence from a Randomized Experiment in Mexico. American Journal of Political Science 57(1): 1-14. 
DELlMUTH, L. M. - STOFFEL, M. F., 2012: Distributive Politics and Intergovernmental Transfers: The Local Allocation of European Union structural funds. European Union Politics 13(3): 413-433.

DIXIT, A. - LONDREGAN, J., 1996: The Determinants Of Su-Ccess of Special Interests In Redistributive Politics. The Journal Of Politics 58(4): 1132-1155.

DOWNS, A., 1957: An Economic Theory of Political Action in a Democracy. Journal of Political Economy 65(2): 135-150.

EVANS, D., 2004: Greasing the Wheels. Using Pork Barrel Projects to Build Majority Coalitions in Congress. Cambridge: Cambridge University Press.

EVANS, T., 2006: The Effects of Discretionary Federal Spending on Parliamentary Election Results. Economic Inquiry 44(2): 234-248.

GOLDEN, M. - PICCI, L., 2008: Pork-Barrel Politics in Postwar Italy, 1953 - 1994. American Journal of Political Science 52(2): 268.

HÁNA, D. - MACEŠKOVÁ, M., 2010: Poslanecké dotace v kontextu implikací pro regionální rozvoj. E M Ekonomie a Management / E M Economics (3): 16-25.

HÁNA, D., 2014: Local Development Implications of Pork-Barrel: A Case Study of a Czech District. Acta Universitatis Carolinae Geographica 49(2): 73-86. DOI: https://doi.org/10.14712/23361980.2014.17.

HLAVAC, M., 2016: Census 2011 in the Slovak Republic - Data Set. Slovak Data Project, 9 August 2016.

HOARE, A. G., 1992: Transport Investment and the Political Pork Barrel: A Review and the Case of Nelson, New Zealand. Transport Reviews 12(2): 133-151.

INEKO - Hospodárenie obcí, nedatované (http://www.hospodarenieobci.sk/).

KHEMANI, S., 2003: Partisan Politics and Intergovernmental Transfers in India. Policy research working paper 3016. (http://elibrary.worldbank.org/doi/abs/10.1596/1813-9450-3016).

KLINGENSMITH, J. Z., 2019: Using Tax Dollars for Re-Election: The Impact of Pork-Barrel Spending on Electoral Success. Constitutional Political Economy 30: 31-49.

KOVÁČ, P., 2016: Ihriská a hasičské autá rozdá Smer aj v tomto volebnom období (https://domov.sme.sk/c/20256175/ihriska-a-hasicske-auta-rozda-smer-aj-v-tomtovolebnom-obdobi.html).

KOVÁČ, P., 2019: Kampaň za štátne nielen pri policajtoch. Saková obchádza obce a rozdáva hasičské autá (https://domov.sme.sk/c/22274988/sakova-ide-vkalinakovych-slapajach-pred-volbami-obchadza-obce-a-rozdava-hasicskeauta.html).

LEIGH, A., 2008: Bringing Home the Bacon: An Empirical Analysis of the Extent and Effects of Pork-Barreling in Australian Politics. Public Choice 137: 279-299.

LEVITT, S. D. - SNYDER, J. M., 1997: The Impact of Federal Spending on House Election Outcomes. Journal Of Political Economy 105(1): 30-53.

MADLEŇÁK, T., 2012: Regionálna diferenciácia volebného správania na Slovensku (1998 - 2010). VEDA, Bratislava.

MAYHEW, D., 1974: Congress: The Electoral Connection. Yale university press.

MESEŽNIKOV, G. 2004. National Populism in Slovakia - Defining the Character of the State and Interpreting Select Historic Events. In: Petőcz, K. (Ed.): National 
Populism and Slovak - Hungarian Relations in Slovakia 2006 - 2009. Šamorín: Forum Minority Research Institute, 39-66.

MIKUŠOVIČ, D., 2017: Ked' Kaliňák pred vol'bami kupoval vozíky pre obce, vít’aza vopred vychválil a platil viac ako v e-shope (https:/e.dennikn.sk/696178/kedkalinak-pred-volbami-kupoval-voziky-pre-obce-vitaza-vopred-vychvalil-a-statplatil-viac-ako-v-e-shope/).

MILLIGAN, K. - SMART, M., 2005: Regional Grants As Pork Barrel Politics. CESifo Working Paper No. 1453. http://papers.ssrn.com/sol3/papers.cfm?abstract_id=710903).

OLIVER, J. E. et al., 2012: Local Elections and the Politics of Small-Scale Democracy. Princeton: Princeton University Press.

PAPP, Z., 2019: Votes, Money Can Buy. The Conditional Effect of EU Structural Funds on Government MPs' Electoral Performance. European Union Politics 20(4): 543-561. DOI: https://doi.org/10.1177/1465116519862875.

PETÖCZ, K., 2004: Slovakia Since 2004 - National Populism and the Hungarian Issue. In: Petőcz, K. (Ed.): National Populism and Slovak - Hungarian Relations in Slovakia 2006 - 2009. Šamorín: Forum Minority Research Institute, 67-98.

PINK, M. et al., 2012: Volební mapy České a Slovenské republiky po roce 1993: vzorce, trendy, proměny. Brno: CDK, 261 s. Politologická řada. ISBN 978-807325-287-288.

Programové vyhlásenie Vlády SR na obdobie rokov 2010 - 2014. (https://www.vlada.gov.sk/data/files/18_programove-vyhlasenie-2010.pdf).

SAMUELS, D. J., 2002: Pork Barreling is not Credit Claiming Or Advertising: Campaign Finance and the Sources of the Personal Vote in Brazil. The Journal of Politics 64 (3): 845-863.

SCHRAFF, D., 2014: Buying Turnout or Rewarding Loyalists? Electoral Mobilization and EU Structural Funding in the German Länder. European Union Politics 15(2):277-288. DOI:10.1177/1465116513509308.

SIDMAN, A. H., 2019: Pork Barrel Politics: How Government Spending Determines Elections in a Polarized Era. New York: Columbia University Press.

SOLÉ-OLLÉ, A. - SORRIBAS-NAVARRO, P., 2008: The Effects of Partisan Alignment on the Allocation of Intergovernmental ransfers. Differences-inDifferences Estimates for Spain. Journal of Public Economics 92(12): 2302-2319. DOI: https://doi.org/10.1016/j.jpubeco.2007.06.014.

SPÁČ, P. - HAVLÍK, V., 2015: Overcoming the Danger of Incumbency: The Case of Smer Party in Slovakia. ECPR General Conference in Montreal.

SPÁČ, P. et al., 2018. Politika vykrmování na regionální úrovni. Př́ípad dotací pro obce ve Středočeském kraji. Czech Sociological Review 54(4): 499-528. DOI: https://doi.org/10.13060/00380288.2018.54.4.412.

SPÁČ, P., 2016. Distribúcia verejných zdrojov ako politický mechanizmus: Prípad environmentálnych dotácií na Slovensku. Sociológia 48(4): 399-419.

SPÁČ, P., 2020: Pork Barrel Politics and Electoral Returns at the Local Level. Public Choice. DOI: https://doi.org/10.1007/s11127-020-00841-2.

STEIN, R. M. - BICKERS, K. N.,1994: Congressional Elections and the Pork Barrel. The Journal of Politics 56(2): 377-399. DOI: https://doi.org/00223816. 
STOKES, S. C. et al., 2013: Brokers, Voters, and Clientelism: The Puzzle of Distributive Politics New York: Cambridge University Press.

STRATMANN, T. - BAUR. M., 2002. Plurality Rule, Proportional Representation, and the German Bundestag: How Incentives To Pork-Barrel Differ Across Electoral Systems. American Journal of Political Science 46(3): 506-514.

DOI: https://doi.org/10.2307/3088395.

STRATMANN, T., 2013:The Effects of Earmarks on the Likeli-Hood of Reelection. European Journal of Political Economy 32: 341-355.

DOI: https://doi.org/10.1016/j.ejpo-leco.2013.08.001.

Štatistický úrad SR (http://www.statistics.sk/).

TASR, 2015: R. Kaliňák odovzdával opät hasičské autá. Prijal pozvanie aj do tanca (https://www.teraz.sk/regiony/vychod-dobrovolnici-hasicske-auta-tanec-/140372clanok.html).

THACHIL, T., 2011: Embedded Mobilization. Nonstate Service Provision as Electoral Strategy in India. World Politics 63(3): 434-469.

TRANSPARENCY INTERNATIONAL SLOVENSKO, 2015: Hasí Kaliňák pokles preferencií za štátne? (https://transparency.sk/sk/hasi-kalinak-pokles-preferencii-zastatne/)

VEIGA, L. G. - VEIGA, F. J., 2013: Intergovernmental Fiscal Transfers as Pork Barrel. Public Choice 155(3-4): 335-353.

VYHLÁŠKA MINISTERSTVA VNÚTRA SR 30/2017 Z.z. (https://www.slovlex.sk/static/pdf/2017/30/ZZ_2017_30_20170301.pdf).

VYHLÁŠKA MINISTERSTVA VNÚTRA SR 201/2015 Z.z. (https://www.slovlex.sk/pravne-predpisy/SK/ZZ/2015/201/).

WEINGAST, B. R. - SHEPSLE, K. A. - JOHNSEN, C., 1981: The Political Economy of Benefits and Costs: A Neoclassical Approach to Distributive Politics. Journal of Political Economy 89(4): 642-64. 